\title{
Estimated Variance Components and Breeding Values for Pre-Weaning Growth Criteria in Romney Sheep
}

\author{
Faid-Allah E ${ }^{1}$, Ghoneim E ${ }^{1}$, Ibrahim $\mathrm{AHM}^{2}$ \\ ${ }^{1}$ Department of Animal Production, Faculty of Agriculture, Minoufiya University, Egypt \\ ${ }^{2}$ Department of Animal Breeding, Desert Research Center, Ministry of Agriculture and Land Reclamation, Egypt \\ E-mail: ifaidallah@yahoo.com
}

(received 24-04-2016; revised 17-05-2016; accepted 09-06-2016)

\begin{abstract}
ABSTRAK
Faid-Allah E, Ghoneim E, Ibrahim AHM. 2016. Estimasi komponen varian dan nilai pemuliaan kriteria pertumbuhan pra-sapih pada domba Romney. JITV 21(2): 73-82. DOI: http://dx.doi.org/10.14334/jitv.v21i2.1353

Penelitian ini dilakukan untuk melihat komponen-komponen ragam, pengaruh genetik langsung, parameter genetik maternal, estimasi nilai pemuliaan (EBV) dan faktor-faktor yang mempengaruhi kriteria pertumbuhan pra-sapih pada domba Romney. Data yang diperoleh merupakan data periode tahun 2006-2012 dari 4989 ekor anak domba yang merupakan keturunan dari 76 domba Romney jantan dan 2190 domba Romney betina yang dibudidayakan di S. Island, New Zeland melalui Gene Marker Laboratorium, Fakultas Pertanian dan Ilmu Hayati (Faculty of Agriculture and Life Science), Universitas Lincoln, New Zeland. Hasil penelitian membuktikan bahwa faktor genetik dan non-genetik memiliki pengaruh nyata $(\mathrm{P}<0.05)$ terhadap faktor-faktor kriteria yang diteliti. Estimasi genetik dan lingkungan bobot hidup saat lahir (LBW), saat penyapihan (LWW) dan rasio Kleiber $(\mathrm{KR})$ berturut-turut adalah sebesar $0.20 \pm 0.074,0.15 \pm 0.042$ dan $0.14 \pm 0.052$ untuk heretabilitas langsung $\left(\mathrm{h}^{2} \mathrm{a} \pm \mathrm{SE}\right) ; 0.59 \pm 0.219$, $0.41 \pm 0.023$ dan $0.08 \pm 0.002$ untuk heritabilitas maternal $\left(h^{2} \mathrm{~m} \pm \mathrm{SE}\right) ; 0.11684,2.6378$ dan 0.27565 untuk ragam aditif $\left(\sigma^{2} \mathrm{a}\right)$; $0.34596,7.1179$ dan 0.14532 untuk ragam maternal $\left(\sigma^{2} \mathrm{~m}\right)$; dan $0.002395,10.1262$ dan 0.509339 untuk ragam lingkungan tetap $\left(\sigma^{2} \mathrm{e}\right)$. EBV dari LBW, LWW dan KR berturut-turut berkisar antara $-0.555: 0.502,-1.554: 3.006$ dan $-0.633: 0.242$ untuk pengaruh genetik langsung, $-0.863: 0.954,-4.942: 2.554$ and $-0.469: 0.179$ untuk maternal domba jantan serta $-0.664: 0.830$, $-2.996: 4.586$ dan $-1.651: 0.677$ untuk pengaruh genetik langsung, $1.429: 1.142,-7.541: 4.920$ dan $-1.223: 0.492$ untuk maternal domba betina. Hasil penelitian ini juga menunjukkan pentingnya mempertimbangkan faktor-faktor non-genetik dalam performan pertumbuhan pra-sapih anak domba. Heritabilitas sedang dan koefisien positif dari fenotipe dan hubungan genetik antar kriteria yang diteliti berpeluang untuk dapat dikembangkan melalui seleksi tradisional.
\end{abstract}

Kata Kunci: Domba Romney, Faktor Genetik, Faktor Non-Genetik, Heritabilitas, Pertumbuhan Pra-Sapih, EBV

\section{ABSTRACT}

Faid-Allah E, Ghoneim E, Ibrahim AHM. 2016. Estimated variance components and breeding values for pre-weaning growth criteria in Romney sheep. JITV 21(2): 73-82. DOI: http://dx.doi.org/10.14334/jitv.v21i2.1353

This study was carried out to investigate variance components, direct, maternal genetic parameters, estimated breeding values and factors affecting pre-weaning growth criteria of Romney sheep. Data were collected over the period from 2006 to 2012 with records of 4989 lambs descended from 76 rams and 2190 ewes of Romney sheep maintained at S. Island of New Zealand via Gene Marker Lab., Faculty of Agric. and Life Sci., Lincoln Univ., New Zealand. Results proved that genetic and non-genetic factors affecting studied criteria had significant effects $(\mathrm{P}<0.05)$. Genetic and environmental estimates of live body weights at birth (LBW), weaning (LWW) and Kleiber ratio (KR) were $0.20 \pm 0.074,0.15 \pm 0.042$ and $0.14 \pm 0.052$ for direct heritability $\left(\mathrm{h}^{2} \mathrm{a} \pm \mathrm{SE}\right) ; 0.59 \pm 0.219,0.41 \pm 0.023$ and $0.08 \pm 0.002$ for maternal heritability $\left(\mathrm{h}^{2} \mathrm{~m} \pm \mathrm{SE}\right) ; 0.11684,2.6378$ and 0.27565 for additive variances $\left(\sigma^{2} \mathrm{a}\right), 0.34596,7.1179$ and 0.14532 for maternal variances $\left(\sigma^{2} \mathrm{~m}\right)$; and $0.002395,10.1262$ and 0.509339 for permanent environmental variances $\left(\sigma^{2} \mathrm{e}\right)$, respectively. EBV's of LBW, LWW and KR ranged from -0.555: 0.502, -1.554: 3.006 and -0.633: 0.242 direct, $-0.863: 0.954,-4.942: 2.554$ and $-0.469: 0.179$ maternal for rams, respectively; and -0.664: 0.830, 2.996: 4.586 and -1.651: 0.677 direct, 1.429: 1.142, -7.541: 4.920 and -1.223: 0.492 maternal for ewes, respectively. Results suggest the importance of considering the non-genetic factors in pre-weaning growth performance of lambs. Moderate heritability and positive coefficients of phenotypic and genetic correlation for studied criteria indicate to the possibility of improving them using traditional selection.

Key Words: Romney Sheep, Genetic Factors, Non-Genetic Factors, Heritability, Pre-Weaning Growth, EBV

\section{INTRODUCTION}

Growth potential of lambs is very important in the sheep production. It is essential to have knowledge of genetic parameters for these economically important criteria to formulate breeding strategies for better production (Gowane et al. 2015). The relative importance of direct and maternal additive genetic effects for growth should be considered when sheep producers formulate their breeding plans (Talebi et al. 
2007). Maternal genetic effects arise from allelic differences between individual mothers at loci influencing offspring phenotype and are a heritable component of phenotypic variance themselves. It can dampen response to the selection, when direct-maternal genetic covariance is negative, or accelerate, when direct-maternal genetic covariance is positive (Wolf et al. 1998). Maternal care and genetic potential of lambs are two factors affecting the early growth of lambs. In the pre-weaning period, animals are fed by their mother's milk (Ghafouri-Kesbi 2013). Growth criteria are influenced by many factors includes additive genetic effects, maternal genetic effects and non-genetic factors (Farokhad et al. 2010). Adjustments of data for environmental factors, such as year or/and season of birth, parity of ewe, type of birth, sex of lamb and location are necessary to obtain reliable estimates and to increase the accuracy of selection of breeding animals (Thiruvenkadan et al. 2011). Studies of estimated breeding value, variance components, genetic parameters, and factors affecting growth criteria in New Zealand Romney sheep were infrequent for the last decade. However, Sheep production has been the important source of sustainable livelihood of the rural folk in New Zealand.

A strategy to increase the efficiency of meat production in both the traditional and intensive systems is the selection of animals regarding the efficiency of feed utilization. Since individual sheep differ in their ability to utilize feed efficiently, selecting the most efficient animals, those with lower maintenance requirements, results in a significantly lower production cost (Ghafouri-Kesbi et al. 2011). Direct selection for lower maintenance requirements is difficult. However, measures of feed efficiency such as Kleiber ratio would be used to achieve this goal (Arthur et al. 2001). Estimated Breeding Value (EBV) is a prediction of the genetic merit of an animal for selection criteria such as growth, milk, and prolificacy. EBVs increase the accuracy of selection for superior performance.

This study investigated genetic and non-genetic factors affecting pre-weaning growth criteria of New Zealand Romney sheep breed and estimate its breeding values, variance components, direct, and maternal genetic parameters.

\section{MATERIALS AND METHODS}

\section{Animal data}

Data were collected over the period from 2006 to 2012 except 2011 with records for studied criteria on total of 4989 pedigree lambs descended from 76 rams and 2190 ewes from 14 commercial farms of Romney sheep maintained at S. Islands of New Zealand via Gene Marker Lab., Faculty of Agric. and Life Sciences, Lincoln Univ., New Zealand. The pedigree data included birth and weaning weight and its dates, sex of lamb, ewe parity, and type of birth. Lambs were weaned at about three months of age. Studied pre-weaning growth criteria were live body weights at birth (LBW), weaning $(\mathrm{LWW})$ and Kleiber ratio $(\mathrm{KR}=$ ADG_LWW/LWW ${ }^{0.75}$ ). Kleiber ratio is defined as growth rate divided by body mass powered 0.75 [metabolic weight] (Kleiber 1947). The breeding season started from February to late May. Those selected rams and ewes were divided into mating groups to avoid inbreeding. Ewes were joined in a pen with a single ram in a group of 40-50 ewes. After mating, ewes were separated from rams and kept as one group until the lambing season which usually starts in August to October.

\section{Statistical analysis}

Data were analyzed by general linear model via Statistical Analysis System [SAS] (SAS 2002), to estimate effect of ram, ewe within ram, year of birth, parity of ewe, sex of lamb, type of birth and farm on three pre-weaning growth criteria: LBW, LWW, and KR. Statistical models used to analyze pre-weaning growth criteria may be written as the following formula:

$$
\begin{aligned}
& \mathrm{Y}_{\mathrm{ijklmnop}}= \mu+\mathrm{S}_{\mathrm{i}}+\mathrm{D}_{\mathrm{j}}+\mathrm{Y}_{\mathrm{k}}+\mathrm{P}_{1}+\mathrm{G}_{\mathrm{m}}+\mathrm{B}_{\mathrm{n}}+\mathrm{F}_{\mathrm{o}} \\
&+\mathrm{e}_{\mathrm{ijklmnop}} \\
& \mathrm{Y}_{\mathrm{ijklmnop}}= \mu+\mathrm{S}_{\mathrm{i}}+\mathrm{D}_{\mathrm{j}}+\mathrm{Y}_{\mathrm{k}}+\mathrm{P}_{1}+\mathrm{G}_{\mathrm{m}}+\mathrm{B}_{\mathrm{n}}+\mathrm{F}_{\mathrm{o}} \\
&+\beta_{(\text {age at weaning }} \text { ijklmno } \\
&
\end{aligned}
$$

where:

Y1 $=$ the observed records on the criterion (LBW)

$\mathrm{Y} 2=$ the observed records on the criteria (LWW,KR)

$\mu \quad=$ the overall mean

$\mathrm{S}_{\mathrm{i}} \quad=$ the random effect of $\mathrm{i}^{\text {th }}$ ram, $\mathrm{i}=1, ., 76$,

$D_{j} \quad=$ the random effect of $j^{\text {th }}$ ewe within ram, $j=$ $1, ., 2190$

$\mathrm{Y}_{\mathrm{k}} \quad=$ the fixed effect of $\mathrm{k}^{\text {th }}$ year of birth, $\mathrm{k}=1, . .6$

$\mathrm{P}_{1} \quad=$ the fixed effect of $\mathrm{l}^{\text {th }}$ parity of ewe: $\mathrm{l}=1, \ldots, 3$

$\mathrm{G}_{\mathrm{m}} \quad=$ the fixed effect of $\mathrm{m}^{\text {th }}$ sex of lamb, $\mathrm{m}=1,2$

$\mathrm{B}_{\mathrm{n}} \quad=$ the fixed effect of $\mathrm{n}^{\text {th }}$ type of birth, $\mathrm{n}=1$, $\ldots, 3$

$\mathrm{F}_{\mathrm{o}} \quad=$ the fixed effect of $\mathrm{o}^{\text {th }}$ farm, $\mathrm{o}=1, \ldots, 14$

$\beta_{\text {agew }}=$ the linear regression coefficient of body weight on age at weaning as a covariate

$\mathrm{e}_{\mathrm{ijklmno}}=$ residual random error. 
Estimation of variance components, direct and maternal genetic parameters and estimated breeding value (EBV) via BLUP (Best Linear Unbiased Prediction) were carried out by derivative-free REML with a simplex algorithm using the Multiple Trait Derivative-Free Restricted Maximum Likelihood [MTDFREML] (Boldman et al. 1995). Models in matrix notation were as follow:

$$
\begin{aligned}
& Y_{1}=X \beta_{1}+Z_{a} a+Z_{m} m+Z_{c} c+e \\
& Y_{2}=X \beta_{2}+Z_{a} a+Z_{m} m+Z_{c} c+e
\end{aligned}
$$

where:

$$
\begin{aligned}
& \mathrm{Y}_{1}= \text { vector of observations (LBW) } \\
& \mathrm{Y} 2= \text { vector of observations (LWW, KR) } \\
& \mathrm{X}= \text { incidence matrix for fixed effects and } \\
& \text { covariates } \\
& \beta_{1}= \text { vector of fixed effects (i. e. year of birth, } \\
& \text { parity of ewe, sex of lamb, birth of rank, } \\
& \text { farm) } \\
&= \text { vector of fixed effects and covariates } \\
& \text { (i. e. fixed effect = year of birth, parity of } \\
& \text { ewe, sex of lamb, birth type, and farm; } \\
& \text { covariate = age at weaning) } \\
& \beta_{2}= \text { incidence matrix for random effects } \\
&= \text { vector of random effects (additive } \\
& \text { genetic, maternal genetic and permanent } \\
& \text { environmental effect) } \\
& \mathrm{Z}= \text { vector of residual effects }\left(0, \mathrm{I} \sigma_{\mathrm{e}}^{2}\right) . \\
& \mathrm{a}, \mathrm{m}, \mathrm{c}
\end{aligned}
$$

\section{RESULTS AND DISCUSSION}

\section{Descriptive statistics}

Table (1) shows the mean, standard deviation (SD) and coefficient of variability $(\mathrm{CV})$ of studied preweaning growth criteria. Live body weights at birth weaning and Kleiber Ratio were $5.573 \pm 0.8848 \mathrm{~kg}(\mathrm{CV}=$ $15.88 \%), \quad 32.48 \pm 5.7534 \mathrm{~kg} \quad(\mathrm{CV}=17.71 \%)$ and $22.39 \pm 2.2246(\mathrm{CV}=9.93 \%)$ for 4989 records of pedigreed Romney lambs weaned at $88.13 \pm 6.75$ days, respectively.

Body weights at birth and weaning in Romney lambs literature were $4.10 \pm 0.76,4.32,4.85 \pm 0.607$ and $5.97 \pm 0.02 \mathrm{~kg}$ of birth weight (Morris et al. 1996; Morris et al. 2000; Everett-Hincks et al. 2014; Ibrahim 2015, respectively); and $28.7 \pm 3.1,28.71$ and $36.81 \pm 0.11 \mathrm{~kg}$ of weaning weight (Morris et al. 1996; Morris et al. 2000; Ibrahim 2015, respectively).

In other sheep breeds, body weights were 2.8 , $3.36 \pm 0.65,4.12 \pm 0.65,4.02 \pm 0.85$ and $3.05 \pm 0.54 \mathrm{~kg}$ at birth and 17.8, 12.69 $\pm 2.38,20.72 \pm 4.33,21.65 \pm 5.53$ and $14.53 \pm 3.20 \mathrm{~kg}$ at weaning, in Zimbabwe Sabi lambs (Matika et al. 2001), in Egyptian Farafra lambs (Mousa et al. 2006), in Iranian Zandi lambs (Ghafouri-Kesbi \& Eskandarinasab 2008), in Arman lambs (Farokhad et al. 2011) and in Indian Malpura lambs (Gowane et al. 2015), respectively. Ghafouri-Kesbi (2013) reported that statistics of Kleiber Ratio at pre-weaning period were $19.61 \pm 2.4(\mathrm{CV}=12.2 \%)$ in fat-tailed Mehraban lambs.

\section{Genetic and non-genetic factors}

Table (2) shows that rams and ewes as random factors significantly $(\mathrm{P} \leq 0.01)$ affected the studied preweaning growth criteria in Romney sheep. Early growth traits were found to be significantly $(\mathrm{P} \leq 0.05)$ affected by ram and ewe in the previous studies carried out by Abbas et al. (2010) in Rahmani and Chios sheep; Esmailizadeh et al. (2011) in Kurdi, Chaal, Afshari and Sanjabi sheep; Màrquez et al. (2012) in Charollais, Suffolk and Texel sheep and Petrović et al. (2013) in Mis and Wurttemberg sheep. In addition, Table 2 shows that all non-genetic effects had significant $(\mathrm{P} \leq 0.01)$ effects on studied criteria. GLM test for these criteria indicated that lamb growth characteristics at preweaning were high values for single lambs, lambs born to third parity ewes. Growth advantage of single born might be resulted from its lower competition to milking and supply from the ewe in gestation period than the multiplex (Mousa et al. 2013). This result is in agreement with Roshanfekr et al. (2011, Arabi); Abbasi et al. (2012, Iranian Baluchi, Kurdish); Everett-Hincks et al. (2014, New Zealand breeds) and Simeonov et al. (2015, Blackhead Pleven).

Also, male lambs had higher values for these criteria in comparison with female lambs. The sex difference is consistent as reported by Mohammadi et al. (2010a), Mandal et al. (2012), Mousa et al. (2013) and EverettHincks et al. (2014).

Table 1. Descriptive statistics of pre-weaning growth criteria in Romney sheep

\begin{tabular}{lcccc}
\hline \hline Pre-weaning growth criteria & Abbreviations & Mean & SD $^{\#}$ & C.V $^{\# \#}$ \\
\hline Live body weight at birth $(\mathrm{kg})$ & LBW & 5.573 & 0.8848 & 15.88 \\
Live body weight at weaning $(\mathrm{kg})$ & LWW & 32.48 & 5.7534 & 17.71 \\
Kleiber ratio & KR & 22.39 & 2.2246 & 9.93 \\
\hline
\end{tabular}

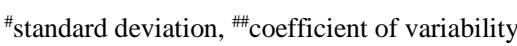


Table 2. Factors affecting pre-weaning growth criteria in Romney lambs

\begin{tabular}{|c|c|c|c|c|c|c|c|c|}
\hline \multicolumn{2}{|c|}{ Factors } & \multirow{2}{*}{$\frac{\text { № }}{76}$} & \multicolumn{2}{|c|}{ LBW (kg) } & \multicolumn{2}{|c|}{ LWW (kg) } & \multicolumn{2}{|c|}{$\mathrm{KR}$} \\
\hline \multirow{2}{*}{ Genetic Factors } & Ram (P-Value) & & $\leq 0.01 * *$ & & $\leq 0.01 * *$ & & $\leq 0.01 * *$ & \\
\hline & Ewe (P-Value ) & 2190 & $\leq 0.001 * * *$ & & $\leq 0.01 * *$ & & $\leq 0.01 * *$ & \\
\hline \multicolumn{2}{|c|}{ Non-Genetic Factors } & & LSM & SD & LSM & SD & LSM & SD \\
\hline \multirow{7}{*}{ Year } & Year-2006 & 1104 & $5.502^{\mathrm{d}}$ & 0.844 & $28.551^{\mathrm{f}}$ & 4.774 & $21.252^{\mathrm{f}}$ & 1.691 \\
\hline & Year-2007 & 998 & $5.166^{\mathrm{e}}$ & 0.948 & $30.332^{\mathrm{e}}$ & 5.098 & $21.445^{\mathrm{e}}$ & 1.720 \\
\hline & Year-2008 & 797 & $5.579^{\mathrm{c}}$ & 0.852 & $34.354^{\mathrm{c}}$ & 5.341 & $22.837^{b}$ & 1.671 \\
\hline & Year-2009 & 871 & $5.863^{\mathrm{a}}$ & 0.807 & $35.990 \mathrm{a}$ & 4.819 & $22.170^{c}$ & 1.586 \\
\hline & Year-2010 & 485 & $5.851^{\mathrm{a}}$ & 0.722 & $32.503^{d}$ & 4.674 & $21.752^{\mathrm{d}}$ & 1.653 \\
\hline & Year-2012 & 734 & $5.695^{\mathrm{b}}$ & 0.854 & $35.163^{\mathrm{b}}$ & 5.047 & $25.734^{\mathrm{a}}$ & 1.554 \\
\hline & P-Value & & $\leq 0.001 * * *$ & & $\leq 0.01 * *$ & & $\leq 0.01 * *$ & \\
\hline \multirow{4}{*}{ Parity } & Parity-1 & 3563 & $5.524^{\mathrm{c}}$ & 0.895 & $32.053^{c}$ & 5.782 & $22.520^{\mathrm{a}}$ & 2.278 \\
\hline & Parity-2 & 1115 & $5.628^{\mathrm{b}}$ & 0.852 & $33.375^{\mathrm{b}}$ & 5.476 & $22.078^{\mathrm{b}}$ & 1.942 \\
\hline & Parity-3 & 311 & $5.934^{\mathrm{a}}$ & 0.784 & $34.322^{\mathrm{a}}$ & 5.258 & $22.380^{\mathrm{a}}$ & 2.322 \\
\hline & P-Value & & $\leq 0.001 * * *$ & & $\leq 0.01 * *$ & & $\leq 0.01 * *$ & \\
\hline \multirow{3}{*}{ Sex } & Sex-Male & 2436 & $5.702^{\mathrm{a}}$ & 0.867 & $33.781^{\mathrm{a}}$ & 5.812 & $22.737^{\mathrm{a}}$ & 2.213 \\
\hline & Sex-Female & 2553 & $5.449^{\mathrm{b}}$ & 0.884 & $31.258^{b}$ & 5.366 & $22.102^{\mathrm{b}}$ & 2.178 \\
\hline & P-Value & & $\leq 0.001 * * *$ & & $\leq 0.001 * * *$ & & $\leq 0.01 * *$ & \\
\hline \multirow{4}{*}{ Birth type } & Birth type- 1 & 816 & $6.210^{\mathrm{a}}$ & 0.674 & $36.065^{\mathrm{a}}$ & 5.243 & $23.047^{\mathrm{a}}$ & 1.968 \\
\hline & Birth type -2 & 3683 & $5.527^{\mathrm{b}}$ & 0.831 & $31.952^{\mathrm{b}}$ & 5.537 & $22.246^{\mathrm{b}}$ & 2.212 \\
\hline & Birth type -3 & 490 & $4.857^{\mathrm{c}}$ & 0.902 & $30.581^{\mathrm{c}}$ & 5.558 & $22.605^{\mathrm{ab}}$ & 2.436 \\
\hline & P-Value & & $\leq 0.001 * * *$ & & $\leq 0.001 * * *$ & & $\leq 0.01 * *$ & \\
\hline \multirow{15}{*}{ Farm } & Farm-1 & 117 & $5.204^{\mathrm{e}}$ & 1.022 & $31.081^{\mathrm{f}}$ & 5.478 & $21.874^{\mathrm{de}}$ & 1.723 \\
\hline & Farm-2 & 168 & $5.607^{\mathrm{ab}}$ & 0.871 & $33.688^{\mathrm{bc}}$ & 5.484 & $21.998 \mathrm{de}$ & 1.640 \\
\hline & Farm-3 & 112 & $5.585^{\mathrm{ab}}$ & 0.816 & $30.071^{\mathrm{g}}$ & 5.304 & $21.407^{\mathrm{g}}$ & 1.818 \\
\hline & Farm-4 & 987 & $5.645^{\mathrm{ab}}$ & 0.864 & $33.449^{\mathrm{bc}}$ & 5.383 & $22.854^{\mathrm{b}}$ & 2.271 \\
\hline & Farm-5 & 152 & $5.623^{\mathrm{ab}}$ & 0.915 & $33.648^{b c}$ & 5.855 & $22.418^{c}$ & 1.692 \\
\hline & Farm-6 & 681 & $5.701^{\mathrm{a}}$ & 0.884 & $33.997^{\mathrm{b}}$ & 5.343 & $22.806^{\mathrm{b}}$ & 2.180 \\
\hline & Farm-7 & 208 & $5.638^{\mathrm{ab}}$ & 0.805 & $35.483^{\mathrm{a}}$ & 5.228 & $25.882^{\mathrm{a}}$ & 1.564 \\
\hline & Farm-8 & 428 & $5.664^{\mathrm{ab}}$ & 0.887 & $32.839^{\text {cde }}$ & 5.555 & $22.722^{\mathrm{b}}$ & 2.365 \\
\hline & Farm-9 & 400 & $5.508^{\mathrm{bc}}$ & 0.935 & $32.063^{\mathrm{e}}$ & 5.685 & $21.936^{\mathrm{de}}$ & 1.684 \\
\hline & Farm-10 & 265 & $5.522^{\mathrm{bc}}$ & 0.852 & $28.881^{\mathrm{h}}$ & 5.294 & $21.276^{\mathrm{g}}$ & 1.913 \\
\hline & Farm-11 & 342 & $5.528^{\mathrm{bc}}$ & 0.932 & $32.402^{\mathrm{de}}$ & 5.832 & $22.181^{\mathrm{cd}}$ & 2.181 \\
\hline & Farm-12 & 307 & $5.411^{\mathrm{cd}}$ & 0.839 & $30.298^{\mathrm{fg}}$ & 5.291 & $21.542^{\mathrm{fg}}$ & 1.631 \\
\hline & Farm-13 & 532 & $5.344^{\mathrm{d}}$ & 0.893 & $30.496^{\mathrm{fg}}$ & 5.383 & $21.723^{\mathrm{ef}}$ & 2.033 \\
\hline & Farm-14 & 290 & $5.720^{\mathrm{a}}$ & 0.746 & $33.195^{\mathrm{bcd}}$ & 6.237 & $22.032^{\mathrm{de}}$ & 1.855 \\
\hline & P-Value & & $0.045^{*}$ & & $0.012 * *$ & & $0.025^{*}$ & \\
\hline
\end{tabular}

${ }^{*}$ Means within classification followed by differ letter are differ significantly (Duncan, 0.05)

LSM $=$ least squares mean

$* \quad=$ significant at the 0.05 level

$* * \quad=$ significant at the 0.01 level

*** $=$ significant at the 0.001 level 
That studied criteria increased from the 1 st to 3 rd parity and thereafter decreased substantially. A similar significant effect of the parity of ewe on the body weights at early parities was observed by Thiruvenkadan et al. (2011) and Simeonov et al. (2015). Lower values for pre-weaning weights for lambs born to younger ewes may be attributed to the relative competition for nutrients between the still growing ewes and the developing fetus (Thiruvenkadan et al. 2011), also depression in these traits for the lambs born after the fourth parity may be due to the ewe's tooth decay that results in grazing problems followed by decreasing milk production and maternal care for lambs (Mousa et al. 2013).

Average of each criterion fluctuated from year to year. These differences in LBW, LWW and KR among lambs born in different years may be attributed to the differences in environmental conditions especially the rainfall level affecting quantity and quality of grasses. Our results are in agreement with the results obtained, in different sheep breeds, by Roshanfekr et al. (2011), Abbasi et al. (2012) and Simeonov et al. (2015) in Arabi, Iranian Baluchi and Blackhead Pleven, respectively.

The farm had significant effect on the studied criteria, This effect may be due to the differences in management and ram of service, that agreed with the results of Thiruvenkadan et al. (2011), Everett-Hincks et al. (2014) and Simeonov et al. (2015).

\section{Genetic parameters}

\section{Variance components}

Table (3) shows estimates additive genetic variance $\left(\sigma_{a}^{2}\right)$, maternal genetic variance $\left(\sigma_{m}^{2}\right)$, permanent environmental variance $\left(\sigma_{e}^{2}\right)$, phenotypic variance $\left(\sigma_{p}^{2}\right)$ and correlation between additive and maternal additive genetic effects $\left(r_{a m}\right)$ for different criteria. Estimates of variance components showed that the estimates of $\sigma_{a}^{2}$ were nearly half the estimates of $\sigma_{m}^{2}$ indicating the importance of maternal additive genetic effects on the criteria.

Also, the $\sigma_{a}^{2}$ was found to account for a small proportion and $\sigma_{e}^{2}$ was found to account for a large proportion of the $\sigma_{p}^{2}$ for all the studied criteria. This result reflects the importance of $\sigma_{e}^{2}$ than $\sigma_{a}^{2}$ which is possibly due to uterine capacity, feeding level at late gestation, and maternal behavior of ewe. Reasonably higher maternal additive effects than direct additive effects were observed by El-Awady et al. (2011) and Mousa et al. (2013) for LBW and results obtained by El-Awady et al. (2011) for LWW.

\section{Heritability}

Estimation of additive $\left(h^{2}\right)$ and maternal $\left(h^{2}{ }_{m}\right)$ heritabilities and genetic $\left(r_{G}\right)$ and phenotypic $\left(r_{p}\right)$ correlations between the studied criteria are shown in Table (4). These presented results showed that the estimation of $h^{2}$ for LBW and LWW were nearly half the estimates of $h^{2}$, indicating to the importance of maternal effects in sheep which contribute to the dependence of lambs on their mother's milk until the time of weaning (Bradford 1972). Morris et al. (1996) worked on New Zealand Romney sheep and reported that heritability estimation for LBW and LWW were $0.29 \pm 0.05$ and $0.11 \pm 0.05$, respectively. Everett-Hincks et al. (2014) worked on New Zealand sheep breeds and reported that direct heritability estimates for LBW ranged from $0.126 \pm 0.009$ to $0.138 \pm 0.009$ and maternal heritability estimates for LBW ranged from $0.179 \pm 0.009$ to $0.316 \pm 0.01$.

Table 3. Variance components for pre-weaning growth criteria in Romney sheep

\begin{tabular}{lcccc}
\hline \hline \multirow{2}{*}{ Criteria } & \multicolumn{2}{c}{ Genetic variance } & Phenotypic variance $\left(\sigma_{\mathrm{p}}^{2}\right)$ & Permanent environmental variance $\left(\sigma^{2} \mathrm{e}\right)$ \\
\cline { 2 - 4 } & Direct $\left(\sigma_{\mathrm{a}}^{2}\right)$ & Maternal $\left(\sigma_{\mathrm{m}}^{2}\right)$ & & 0.002395 \\
LBW & 0.11684 & 0.34596 & 0.58784 & 10.1262 \\
LWW & 2.6378 & 7.1179 & 17.297 & 0.509339 \\
KR & 0.27565 & 0.14532 & 1.9125 & \\
\hline
\end{tabular}

Table 4. Heritability and additive maternal genetic correlation for pre-weaning growth criteria in Romney sheep

\begin{tabular}{lccc}
\hline \hline \multirow{2}{*}{ Criteria } & \multicolumn{3}{c}{ Estimates of heritability and additive maternal genetic correlation } \\
\cline { 2 - 4 } & Direct $\left(\mathrm{h}^{2}{ }_{\mathrm{a}}\right)$ & Maternal $\left(\mathrm{h}^{2} \mathrm{~m}\right)$ & $\mathrm{r}_{\mathrm{g}(\mathrm{d}, \mathrm{m})}$ \\
\hline LBW & $0.20 \pm 0.074$ & $0.59 \pm 0.219$ & $0.471 \pm 0.083$ \\
LWW & $0.15 \pm 0.042$ & $0.41 \pm 0.023$ & $0.416 \pm 0.132$ \\
KR & $0.14 \pm 0.052$ & $0.08 \pm 0.002$ & $0.703 \pm 0.435$ \\
\hline
\end{tabular}


Ghafouri-Kesbi (2013) reported that estimates of direct, maternal heritability, $\sigma^{2} \mathrm{a}, \sigma^{2} \mathrm{~m}, \sigma^{2} \mathrm{e}$ and $\sigma^{2} \mathrm{p}$ for pre-weaning Kleiber Ratio were $0.13 \pm 0.03$, $0.08 \pm 0.03$, $0.21,0.13,1.21$ and 1.66 , respectively. In addition, there is a positive genetic correlation between KR with traits related to growth (Abegas et al. 2005, GhafouriKesbi et al. 2011). These findings show that improvements in feed efficiency could be made without negatively affecting body weight or growth rate (Ghafouri-Kesbi 2013). These findings are in accordance with other reports (Abegas et al. 2005; Szwaczkowski et al. 2006; Mohammadi et al. 2010b; Ghafouri-Kesbi et al. 2011; Savar-Sofla et al. 2011; Mokhtari et al. 2012).

Supakorn et al. (2013) reported that in Thailand sheep populations, estimated direct and maternal heritabilities from multivariate analysis of the model for birth weight were $0.32 \pm 0.06$ and $0.23 \pm 0.02$, respectively.

Aksoy et al. (2016) reported that in Karayaka lamps, the direct heritability of birth weight was $0.44 \pm 0.063$. When the maternal genetic effects were considered in models, the direct heritability for birth weight decreased from 0.36 to 0.24 . The inclusion of the maternal, genetic, and/or environmental effects into the model resulted in a direct additive variance value varied between 0.07 and 0.08 . In model considered maternal genetic and environmental effects, the values for the maternal heritability ranged between 0.15 and 0.22 . Furthermore, depending on the model used, direct heritability estimates for WW ranged between 0.40 and 0.27 . For weaning weight, model 1 provided a direct heritability value of $0.40 \pm 0.066$. For weaning weight, the maternal heritability values within the range of 0.04-0.14 were estimated.

Meyer (1992) suggested that models not considering maternal genetic effects could result in substantially higher estimates of $\sigma^{2}{ }_{a}$ and $h^{2}{ }_{a}$. Also, the estimates of $h^{2}{ }_{a}$ and $h^{2}{ }_{m}$ for LBW were higher than their corresponding estimates for LWW. The decrease in the estimation of both $h^{2}{ }_{a}$ and $h^{2}{ }_{m}$ by age was in the line with the results of El-Awady et al. (2011) and Mousa et al. (2013). Table 4 shows that estimates of direct and maternal heritability for pre-weaning Kleiber Ratio were $0.14 \pm 0.052$ and $0.08 \pm 0.002$, respectively; which ranged between 0.01-0.15 as reported for different sheep breeds (Mohammadi et al. 2010b; GhafouriKesbi et al. 2011; Savar-Sofla et al. 2011; Mokhtari et al. 2012). Furthermore, Kleiber Ratio estimates of heritability ranged from 0.04 (Arman sheep, Mokhtari et al. 2012) to 0.15 (Sanjabi sheep, Mohammadi et al. $2010 b$ ). Estimates of heritability for a criterion may differ between sheep breeds and change slowly over time. Some literature of heritability estimation revealed that in sheep, the Kleiber ratio was a low heritable criterion.

Generally, the obtained results fell in the range reported in the literature for different breeds of sheep maintained at different locations and regions around the world. Range of $h^{2}$ estimates for these criteria in literature varies substantially from 0.004 in Barbary sheep (Bedhiaf et al. 2000) to 0.94 in Hissardale sheep (Chaudhry \& Shah 1985) for LBW; from 0.007 in Barbary sheep (Bedhiaf et al. 2000) to 0.81 in Multibreed meat sheep (Lobo et al. 2009) for LWW. Likewise, the estimates of $h^{2}{ }_{m}$ ranged from 0.02 in Dorper sheep (Neser et al. 2001) to 0.65 in Sangsari sheep (Miraei-Ashtiani et al. 2007) for LBW and from 0.01 in Ghazel sheep to 0.48 in Dorper sheep (Assan et al. 2011) for LWW and from 0.01 in Romanov sheep (Maria et al. 1993) to 0.07 in crossbreed sheep (Hall et al. 1995). Furthermore, direct estimates of heritability tend to be higher than maternal for early growth traits (Hassen et al. 2003). The range of direct heritability estimates for birth weight from multivariate analysis in the literature varies substantially from 0.04 in Romanov and Kermani breeds (Maria et al. 1993; Rashidi et al. 2008) to 0.46 in Menz breed (Gizaw et al. 2007). Talebi et al. (2007) reported that estimates of heritability for LBW and LWW of Lori-Bakhtiari sheep were $0.30 \pm 0.03$ and $0.13 \pm 0.03$ direct and 0.22 and 0.17 maternal, respectively. Consequently, genetic progress is possible for growth traits by selection.

Direct estimates of heritability in sheep breeds for LBW were 0.28 \pm 0.04 in Sabi (Matika et al. 2001), 0.06 in Swedish finewool (Näsholm \& Danell 1996), 0.13 in Suffolk (Yamaki 1994), 0.14-0.20 in Baluchi (Yazdi et al. 1997), 0.43 in Segurena (Analla et al. 1997) and $0.15 \pm 0.05$ in Romney (Ibrahim 2015). Furthermore, estimates for LWW were $0.17 \pm 0.00$ in Sabi (Matika et al. 2001), 0.34 in Suffolk (Yamaki, 1994), 0.15 Swedish finewool (Näsholm \& Danell 1996), 0.13-0.19 Baluchi (Yazdi et al. 1997), 0.31 Segurena (Analla et al. 1997) and $0.08 \pm 0.03$ in Romney (Ibrahim 2015). Gowanea et al. (2015) reported that estimates of direct $h^{2}$ were $0.29 \pm 0.05,0.40 \pm 0.06$, and $0.43 \pm 0.06$ and the maternal estimates were $0.23 \pm 0.04$ and $0.15 \pm 0.03$ for body weights at birth and weaning in Indian Malpura sheep, respectively

\section{Genetic and phenotypic correlations}

Table 5 presents the genetic correlations for LBW with both LWW and KR were 0.325 and 0.048 , respectively, however, the phenotypic correlations between studied criteria ranged from 0.196 to 0.597 as positive and significant coeffecients. 
Table 5. Genetic (above) and phenotypic (below) correlations between pre-weaning growth criteria in Romney sheep

\begin{tabular}{lccc}
\hline \hline Criteria & LBW & LWW & KR \\
\hline LBW & - & 0.325 (direct) & 0.048 (direct) \\
& & 0.348 (maternal) & 0.052 (maternal) \\
LWW & $0.464 * *$ & - & 0.066 (direct) \\
KR & $0.196^{*}$ & $0.597 * *$ & 0.025 (maternal) \\
\hline
\end{tabular}

$*=$ Correlation is significant at the 0.05 level $* *=$ Correlation is significant at the 0.01 level

Estimates of genetic correlations between preweaning criteria in the current study were positive and moderate. On the other hand, the estimation of genetic correlations for the birth weight ranged from $-0.078 \pm 0.0084$ to $-0.127 \pm 0.0450$ as reported by (Everett-Hincks et al. 2014).

Correlation coefficients were 0.38 , and ranged from 0.39 to 0.41 for phenotypic correlation and 0.40 , and ranged from 0.40 to 0.81 for genetic correlation in breeds of Suffolk and Baluchi respectively (Yamaki 1994; Yazdi et al. 1997). In general, the estimates of genetic correlations were agree with those reported by El-Awady et al. (2011) in Egyptian Rahmani lambs and lower than those reported by Rashidi et al. (2008); Roshanfekr et al. (2011); Prakash et al. (2012) in Arabi, Kermani and Malpura breeds of sheep, respectively.

\section{Estimated breeding value}

Estimated Breeding Value (EBV) are expressed as deviations from population mean and sires were ranked based on their genetic merit. For low heritable below 0.15 criteria, an animal's performance is much less useful for identifying the individuals with the best genes for the trait. For this reason, selection for studied traits should be according to estimates of breeding values. Estimates of maternal heritability were high for preweaning criteria as reveal in Table 4. It shows that genes contributing to maternal performance have an equal influence on the early growth of lambs as genes carried by lambs. If maternal genetic effects are not considered, true genetic potential of lambs is masked by maternal performance making it difficult to select superior animals. As a result, maternal effects should be included in the model to obtain accurate estimates of genetic parameters and breeding values, in particular where animals are evaluated for criteria related to early growth.
Table 6 presents the mean, SD, minimum and maximum for direct and maternal estimated breeding values for $\mathrm{LBW}, \mathrm{LWW}$ and $\mathrm{Kr}$ in rams and ewes of Romney sheep. The mean, SD (Min : Max) for Rams were $0.0023 \pm 0.1998(-0.5546: 0.5017)$ direct and $-0.0039 \pm 0.3437(-0.8632: 0.9543)$ maternal EBV for LBW, respectively; were $0.1984 \pm 0.7529(-1.5535$ : $3.0056)$ direct and $-0.3262 \pm 1.2379$ (-4.9417: 2.5542) maternal EBV for LWW, respectively; and were $0.0226 \pm 0.1330 \quad(-0.6333: 0.2417)$ direct and $0.0165 \pm 0.0983(-0.4689: 0.1790)$ maternal EBV for $\mathrm{KR}$, respectively. The estimated breeding values for rams had a wide range of all pre-weaning criteria, so we may select superior rams and using the selected animals in mating as parents of next generation to make genetic improvement in pre-weaning as a selection objective.

The mean, SD (Min : Max) for ewes were $0.0 \pm 0.2307(-0.6638: 0.8302)$ direct and $0.0 \pm 0.3970$ $(-1.4286: 1.1422)$ maternal estimated breeding values (EBV) for $\mathrm{LBW}$, respectively; were $-0.0069 \pm 0.9606$ $(-2.9963: 4.5864)$ direct and $0.0113 \pm 1.5793(-7.5410$ : 4.9195) maternal EBV for LWW, respectively; and were $0.0008 \pm 0.2314(-1.6512: 0.6769)$ direct and $0.0006 \pm 0.1701(-1.2227: 0.4919)$ maternal EBV for $\mathrm{KR}$, respectively. The estimated breeding values for Ewes had a wide range for all pre-weaning criteria, so we may cull lower Ewes in EBV for pre-weaning criteria from next generation to make genetic improvement in pre-weaning as a selection objective.

Jeichitra et al. (2015) reported that the estimates of breeding value $(\mathrm{kg})$ of Mecheri rams for body weights via DFREML as an animal model program ranged from -0.534 to $0.665,-2.592$ to 2.195 for birth and three months weights, respectively. For the same traits, estimated breeding value $(\mathrm{kg})$ by Best Linear Unbiased Prediction (BLUP) and Least-squares (LS) methods ranged from -0.199 to 0.228 and -1.195 to $1.133 ;-1.079$ to 0.902 and -4.727 to 3.526 , respectively. 
Table 6. Estimated breeding values for pre-weaning growth criteria in Romney sheep

\begin{tabular}{|c|c|c|c|c|c|c|c|}
\hline \multicolumn{2}{|c|}{ Item } & \multicolumn{2}{|c|}{ LBW } & \multicolumn{2}{|c|}{ LWW } & \multicolumn{2}{|c|}{$\mathrm{KR}$} \\
\hline & & Direct & Maternal & Direct & Maternal & Direct & Maternal \\
\hline \multirow{4}{*}{$\begin{array}{c}\text { Rams } \\
(№=76)\end{array}$} & Minimum & -0.5546 & -0.8632 & -1.5535 & -4.9417 & -0.6333 & -0.4689 \\
\hline & Maximum & 0.5017 & 0.9543 & 3.0056 & 2.5542 & 0.2417 & 0.1790 \\
\hline & Mean & 0.0023 & -0.0039 & 0.1984 & -0.3262 & -0.0226 & -0.0165 \\
\hline & SD & 0.1998 & 0.3437 & 0.7529 & 1.2379 & 0.1330 & 0.0983 \\
\hline \multirow{4}{*}{$\begin{array}{c}\text { Ewes } \\
\text { (№=2190) }\end{array}$} & Minimum & -0.6638 & -1.4286 & -2.9963 & -7.5410 & -1.6512 & -1.2227 \\
\hline & Maximum & 0.8302 & 1.1422 & 4.5864 & 4.9195 & 0.6769 & 0.4919 \\
\hline & Mean & 0.0000 & 0.0000 & -0.0069 & 0.0113 & 0.0008 & 0.0006 \\
\hline & SD & 0.2307 & 0.3970 & 0.9606 & 1.5793 & 0.2314 & 0.1701 \\
\hline
\end{tabular}

\section{CONCLUSION}

According to the results, it is concluded that the non-genetic factors have the main source of variation for pre-weaning criteria. Estimation of heritability and variance components of the studied criteria proved the importance of maternal effect. Birth weight, weaning weight and Kleiber ratio have been reported as moderately heritable criteria. Positive genetic correlations among these criteria indicate to possibility of improving these criteria using selection program. Furthermore, Kleiber ratio has been recommended as an indirect selection parameter for feed conversion.

\section{ACKNOWLEDGMENT}

The authors wish to thank the Gene Marker Lab., Faculty of Agriculture and Life Science, Lincoln University, New Zealand; for permission to use Romney sheep data giving to Dr A.H.M. Ibrahim while his scientific mission in New Zealand, which funding and supporting via the Partnership and Ownership Initiative, the Egyptian Ministry of Higher Education.

\section{REFERENCES}

Abbas SF, Abd-Allah M, Allam FM, Aboul-Ellah AA. 2010. Growth performance of Rahmani and Chios lambs weaned at different ages. Aust J Basic Appl Sci. 4:15831589 .

Abbasi MA, Abdollahi-Apanahi R, Maghsoudi A, VaezTorshizi R, Nejati-Javaremi A. 2012. Evaluation of models for estimation of genetic parameters and maternal effects for early growth traits of Iranian Baluchi sheep. Small Rumin Res. 104:62-69. doi: 10.1016/j.smallrumres.2011.10.003.

Abegaz S, van Wyk JB, Olivier JJ. 2005. Model comparisons and genetic and environmental parameter estimates of growth and the Kleiber ratio in Horro sheep. S Afr $\mathrm{J}$ Anim Sci. 35:30-40.

Aksoy Y, Ulutaş Z, Şen U, Şirin E, Şahin A. 2016. Estimates of genetic parameters for different body weights and muscle and fat depths of Karayaka lambs. Turk J Vet Anim Sci. 40:13-20. doi: 10.3906/vet-1504-16.

Analla M, Munoz-Scrrano A, Serradila JM. 1997. Analysis of the genetic relationship between litter size and weight traits is Segurena sheep. Can J Anim Sci. 77:17-21.

Arthur PF, Renand G, Krauss D. 2001. Genetic and phenotypic relationships among different measures of growth and feed efficiency in young Charolais bulls. Livest Prod Sci. 68:131-139. doi: 10.1016/S03016226(00)00243-8.

Assan N, Mabuku O, Musasira M. 2011. Estimation of covariance components and genetic parameters for weaning weight in Matebele goat, Sabi, Dorper and Mutton Merino sheep. J Anim Sci Adv. 1:38-46.

Bedhiaf S, Bouix J, Clement V, Bibe B, Francois D. 2000. Choice importance of analysis model for the estimation of genetic parameters of growth of meat sheep in Tunisia. 7èmes Rencontres autour des Recherches sur les Rum. Paris (France): Institut National de la Recherche Agronomique. p. 169-172.

Boldman KG, Kriese LA, Van Vleck LD, Van Tassell CP, Kachman SD. 1995. A manual for use of [MTDFREML] A Set of programs to obtain estimates of variances and covariances. Washington DC (USA): USDA/AES.

Bradford GE. 1972. The role of maternal effects in animal breeding: VII Maternal effects in sheep. J Anim Sci. 35:1324-1334.

Chaudhry MZ, Shah SK. 1985. Heritability and correlation of birth weight, weaning weight and 12 month weight in Lohi, Awassi, Hissardale and Kacchi sheep. Pak Vet J. 5:67-71.

El-Awady HG, Oudah SM, Shalaby NA, El-Arian MN, Metawi HR. 2011. Genetic improvement study on pre- 
weaning body weight of Egyptian Rahmani lambs under a pure breeding production system. In: Bernués A, Boutonnet JP, Casasús I, Chentouf M, Gabiña D, Joy M, López-Francos A, Morand-Fehr P, Pacheco F, editors. Economic soc. Options Méditerranéennes Série A Séminaires Méditerranéens. 100:311-316.

Esmailizadeh AK, Miraei-Ashtiani SR, Mokhtari MS, Asadi Fozi M. 2011. Growth performance of crossbred lambs and productivity of Kurdi ewes as affected by the sire breed under extensive production system. J Agric Sci Technol. 13:701-708.

Everett-Hincks JM, Mathias-Davis HC, Greer GJ, Auvray BA, Dodds KG. 2014. Genetic parameters for lamb birth weight, survival and death risk traits. J Anim Sci. 92:2885-2895. doi: 10.2527/jas.2013-7176.

Farokhad ML, Nassiri MTB, Roshanfekr H, Fayazi J, Mamouei M. 2010. Genetic parameters for direct and maternal effects on growth traits of Arman lambs. Res J Biol Sci. 1:71-74. doi: 10.3923/rjbsci.2010.71.74.

Farokhad ML, Roshanfekr H, Amiri S, Mohammadi K, Mirzadeh K. 2011. Genetic trends estimation for some of the growth traits in Arman sheep. J Anim Vet Adv. 10:1801-1803. doi: 10.3923/javaa.2011.1801.1803.

Ghafouri-Kesbi F. 2013. (Co) variance components and genetic parameters for growth rate and Kleiber ratio in fat-tailed Mehraban sheep. Arch Tierz. 56:564-572. doi: 10.7482/0003-9438-56-055.

Ghafouri-Kesbi F, Abbasi MA, Afraz F, Babaei M, Baneh H, Abdollahi Arpanahi R. 2011. Genetic analysis of growth rate and Kleiber ratio in Zandi sheep. Trop Anim Health Prod. 43:1153-1159. doi: 10.1007/s11250-011-9816-2.

Ghafouri-Kesbi F, Eskandarinasab MP. 2008. An evaluation of maternal influences on growth traits, the Zandi sheep breed of Iran as an example. J Anim Feed Sci. 17:519529. doi: $10.22358 /$ jafs $/ 66679 / 2008$.

Gizaw S, Lemma S, Komen H, Johan AM. 2007. Estimates of genetic parameters and genetic trends for live weight and fleece traits in Menz sheep. Small Rumin Res. 70:145-153. doi: 10.1016/j.smallrumres.2006.02.007.

Gowanea GR, Princea LLL, Lopesb FB, Paswana C, Sharma RC. 2015. Genetic and phenotypic parameter estimates of live weight and daily gain traits in Malpura sheep using Bayesian approach. Small Rumin Res. 128:10-18. doi: 10.1016/j.smallrumres.2015.04.016.

Hall DG, Fogarty NM, Gilmour AR. 1995. Performance of crossbred progeny of Trangie fertility Merino and Booroola Merino rams and Poll Dorset ewes 1 Lamb birth weight, survival and growth. Aust J Experimental Agric. 35:1069-1074.

Hassen Y, Fuerst-Waltl B, SÖlkner J. 2003. Genetic parameter estimates for birth weight, weaning weight and average daily gain in pure and crossbred sheep in Ethiopia J Anim Sci. 120:29-38. doi: 10.1046/j.14390388.2003.00361.x.
Ibrahim AHM. 2015. Variability of prion protein $(\mathrm{PrP})$ gene and its association with productive performance in Barki lambs. J Am Sci. 11:89-96.

Jeichitra V, Rajendran R, Karunanithi K, Rahumathulla PS. 2015. Comparison of three methods for estimating breeding values of Mecheri rams for body weights. Indian J Anim Res. 49:161-164.

Kleiber M. 1947. Body size and metabolic rate. Physiol Rev. 27:511-541

Lobo AMBO, Lobo RNB, Paiva ASR, Oliveira SMPD, Faco O. 2009. Genetic parameters for growth, reproductive and maternal traits in a multi-breed meat sheep population. Genet Mol Biol J. 32:761-770. doi: 10.1590/S1415-47572009005000080.

Mandal A, Dass G, Rout PK. 2012. Genetic analysis of growth and feed conversion efficiency of Muzaffarnagari lambs under intensive feeding system. Int J Livest Prod. 3:47-52. doi: 10.5897/IJLP12.007.

Maria GA, Boldman KG, VanVleck LD. 1993. Estimates of variances due to direct and maternal effects for growth traits of Romanov sheep. J Anim Sci. 71:845-849.

Màrquez GC, Huresign W, Davies MH, Emmans GC, Reehe R, Bunger L, Simm G, Lewis RM. 2012. Index selection in terminal sires improves early lambs growth. J Anim Sci. 90:142-151. doi: 10.2527/jas.2011-4294.

Matika O, van Wyk JB, Erasmus GJ, Baker RL. 2001. Phenotypic and genetic relationships between lamb and ewe traits for the Sabi sheep of Zimbabwe. S Afr J Anim Sci. 313:215-221.

Meyer K. 1992. Variance components due to direct and maternal effects for growth traits of Australian beef cattle. Livest Prod Sci. 31:179-204.

Miraei-Ashtiani SR, Seyedalian SAR, Shahrbabak MM. 2007. Variance components and heritabilities for body weight traits in Sangsari sheep, using univariate and multivariate animal models. Small Rumin Res. 73:109114. doi: 10.1016/j.smallrumres.2006.12.002.

Mokhtari MS, Shahrebabak MM, Shahrebabk HM, Sadeghi M. 2012. Estimation of (co)variance components and genetic parameters for growth traits in Arman sheep. J Livest Sci Technol. 38-47.

Mohammadi K, Aghaei A, Mizadeh KH, Motaghinia G. 2010a. Investigation of maternal effect on early growth traits in Arabi lambs, using single trait animal models. J Anim Sci Vet Adv. 9:1712-1716. doi: 10.3923/javaa.2010.1712.1716.

Mohammadi Y, Rashidi A, Mokhtari MS, Esmailizadeh AK. 2010b. Quantitative genetic analysis of growth traits and Kleiber ratios in Sanjabi sheep. Small Rumin Res. 93:88-93. doi: 10.1016/j.smallrumres.2010.05.005.

Morris CA, Johnson DL, Sumner RMW, Hight GK, Dobbie JL, Jones KR, Wrigglesworth AL, Hickey SM. 1996. Single trait selection for yearling fleece weight or live weight in Romney sheep correlated responses in live 
weight, fleece traits, and ewe reproduction. N Z J Agric Res. 39:95-106. doi: 10.1080/00288233.1996.9513166.

Morris CA, Hickey SM, Clarke JN. 2000. Genetic and environmental factors affecting lamb survival at birth and through to weaning. N Z J Agric Res. 43:515-524. doi: 10.1080/00288233.2000.9513448.

Mousa E, Mona A. Osman, EL-Saied UM. 2006. Genetic parameters for body weight of Egyptain Farafra lambs with random regression model. Egypt $\mathrm{J}$ Anim Prod. 43:57-69.

Mousa E, Monzaly H, Shaat I, Ashmawy. 2013. Factors affecting birth and weaning weights of native Farafra lambs in Upper Egypt. Egypt J Sheep Goat Sci. 8:1-10.

Näsholm A, Danell. 1996. Genetic relationships of lamb weight, maternal ability, and mature ewe weight in Swedish finewool sheep. J Anim Sci. 74:329-339.

Neser FWC, Erasmus GJ, VanWyk JB. 2001. Genetic parameter estimates for pre-weaning weight traits in Dorper sheep. Small Rumin Res. 40:197-202. doi: 10.1016/S0921-4488(01)00172-9.

Petrović V, Petrović MP, Ilić, Z Petrović MM, Milošević B, Ružić Muslić D, Maksimović N. 2013. Effect of genotype, sire, sex, gestation length on birth weight of lambs. Biotechnol Anim Husb. 29:685-693. doi: 10.2298/BAH1304685C

Prakash V, Prince LLL, Gowane GR, Arora AL. 2012. The estimation of (co)variance components and genetic parameters for growth traits and Kleiber ratios in Malpura sheep of India. Small Rumin Res. 108:54-58. doi: 10.1016/j.smallrumres.2012.07.018

Rashidi A, Mokhtari MS, Safi JM, Mohammad AMR. 2008. Genetic parameter estimates of pre-weaning growth traits in Kermani sheep. Small Rumin Res. 74:165-171. doi: 10.1016/j.smallrumres.2007.06.004.

Roshanfekr H, Mamouei M, Mohammadi K, Rahmatnejad E. 2011. Estimation of genetic and environmental parameters affected pre-weaning traits of Arabi lambs. J Anim Vet Adv. 10:1239-1243. doi: 10.3923/javaa.2011.1239.1243.
[SAS] Statistics Analysis System. 2002. Statistics Analysis System: User's guide (Ver 9). North Carolina (US): SAS Institute Inc.

Savar-Sofla S, Nejati-Javaremi A, Abbasi MA, Vaez-Torshizi R, Chamani M. 2011. Investigation on direct and maternal effects on growth traits and the Kleiber Ratio in Moghani Sheep. World Appl Sci J. 14:1313-1319.

Simeonov MS, Harmon DL, Nedelkov KV. 2015. Nongenetic factors affecting birth weight in the lambs of Blackheads Pleven breed. J Anim Sci Adv. 5:12081217. doi: $10.5455 /$ jasa.20150326081131.

Supakorn C, Pralomkarn W, Anothaisinthawee S. 2013. Estimation of genetic parameters and genetic trends for weight and body measurements at birth in sheep populations in Thailand. Songklanakarin J Sci Technol. 35:1-10.

Szwaczkowski T, Wójtowski J, Stanisławska E, Gut A. 2006. Estimates of maternal genetic and permanent environmental effects in sheep. Arch Tierz. 49:186-192.

Talebi MA, Miraei-Ashtiani SR, Nejati-Javaremi A, MoradiShahrbabak M. 2007. Phenotypic and genetic characteristics of growth and carcass traits of LoriBakhtiari sheep. Biotechnol Anim Husbandry. 23:357363. doi: 10.2298/BAH0701357T.

Thiruvenkadan AK, Karunanithi K, Muralidharan J, Narendra BR. 2011. Genetic analysis of pre-weaning and postweaning growth traits of Mecheri sheep under dry land farming conditions. Asian-Australas J Anim Sci. 24:1041-1047. doi: 10.5713/ajas.2011.10361.

Wolf JB, Brodie ED, Cheverud JM, Moore AJ, Wade MJ. 1998. Evolutionary consequences of indirect genetic effects. Trends Ecol Evol. 13:64-69. doi: 10.1016/S0169-5347(97)01233-0.

Yamaki K. 1994. Growth of lambs and genetic parameters in four breeds. Proc 5th World Congr Gen Appl Livest Prod. 18:135-138.

Yazdi MH, Engström G, Nasholm A, Johansson K, Jorjani H, Liljedahl LE. 1997. Genetic parameters for lamb weight at different ages and wool production in Baluchi sheep. J Anim Sci. 65:224-255. 